\title{
PENGARUH KEMAMPUAN BERHITUNG DAN MENYEDERHANAKAN BENTUK ALJABAR TERHADAP KEMAMPUAN MENYELESAIKAN MASALAH TRIGONOMETRI
}

\author{
Yadi Ardiawan \\ Pendidikan Matematika, Fakultas Pendidikan MIPA dan Teknologi IKIP PGRI Pontianak \\ Jalan Ampera Nomor 88 Pontianak - 78116 \\ e-mail: yadi.stkip@gmail.com
}

\begin{abstract}
Abstrak
Penelitian bertujuan untuk mengukur pengaruh kemampuan berhitung dan kemampuan menyederhanakan bentuk aljabar terhadap kemampuan menyelesaikan masalah Trigonometri. Metode penelitian adalah deskriptif dengan bentuk penelitian studi hubungan. Populasi penelitian seluruh mahasiswa Pendidikan Matematika IKIP PGRI Pontianak yang mengambil mata kuliah Trigonometri tahun akademik 2017/2018 sebanyak 100 orang yang terbagi menjadi 3 kelas yaitu kelas AP, BP, dan CP. Sampel adalah mahasiswa kelas AP dengan teknik cluster random sampling. Alat ukur yang digunakan adalah tes kemampuan menghitung, menyederhanakan bentuk aljabar, dan menyelesaikan masalah Trigonometri dalam bentuk esai yang terdiri dari 5 butir soal untuk masing-masing tes. Teknik analisis data menggunakan uji parametrik. Hasil penelitian adalah: (1) Terdapat pengaruh yang positif antara kemampuan berhitung terhadap kemampuan menyelesaikan masalah Trigonometri sebesar $23,4 \%$; (2) Terdapat pengaruh yang positif antara kemampuan menyederhanakan bentuk aljabar terhadap kemampuan menyelesaikan masalah Trigonometri sebesar 19,9\%; dan (3) Terdapat pengaruh yang positif secara bersama-sama antara kemampuan berhitung dan kemampuan menyederhanakan bentuk aljabar terhadap kemampuan menyelesaikan masalah Trigonometri sebesar $29 \%$.
\end{abstract}

Kata Kunci: kemampuan berhitung, kemampuan menyederhanakan bentuk aljabar, kemampuan menyelesaikan masalah Trigonometri.

\begin{abstract}
The research aims to measure the effect of the ability to count and to simplify the form of algebra on the ability to solve Trigonometric problems. The research method was descriptive with a form of relationship study research. The research population was all students of Mathematics Education of IKIP PGRI Pontianak taking Trigonometry courses in the academic year 2017/2018 were 100 people divided into 3 classes, namely AP, BP, and CP classes. Samples are AP class students with a cluster random sampling technique. The measuring instrument used the ability to calculate tests, simplify the form of algebra, and solve Trigonometry problems in the form of essays consisting of 5 items for each test. Data analysis techniques used parametric. The results of the research: (1) There is a positive influence between the ability to count on the ability to solve Trigonometry problems by $23.4 \%$; (2) There is a positive influence between the ability to simplify the form of algebra to the ability to solve Trigonometry problems by 19.9\%; and (3) There is a positive influence jointly between the ability to count and the ability to simplify the form of algebra on the ability to solve trigonometric problems by $29 \%$.
\end{abstract}

Keywords: the ability to count, the ability to simplify the form of algebra, the ability to solve Trigonometric problems. 


\section{PENDAHULUAN}

Melihat antusiasme calon mahasiswa baru yang memilih Program Studi Pendidikan Matematika IKIP PGRI Pontianak yang tinggi, perlu dipersiapkan seleksi yang baik agar calon mahasiswa baru yang diperoleh juga baik. Berdasarkan pengalaman peneliti dalam mengajar di Program Studi Pendidikan Matematika, banyak nilai Trigonometri mahasiswa baru yang memperoleh $\mathrm{C}$, bahkan ada yang D dan E. Hal tersebut menjadi evaluasi bagi peneliti dari tahun ke tahun dengan memperbaiki proses perkuliahan, dari variasi metode pembelajaran, bahan ajar, alat, dan sumber belajar. Akan tetapi, evalusi tersebut belum berdampak yang signifikan dalam peningkatan nilai mata kuliah Trigonometri. Trigonometri merupakan salah satu mata kuliah yang terdapat dalam Kurikulum 2013 Pendidikan Matematika IKIP PGRI Pontianak. Mata kuliah tersebut diajarkan pada semester I (ganjil). Sebelum mengikuti mata kuliah, mahasiswa sudah mempelajari bentuk akar dan pangkat, persamaan, dan kesebangunan dua segitiga. Mata kuliah Trigonometri mempelajari perbandingan trigonometri (sinus, cosinus, tangen); penggunaan perbandingan trigonometri; penentuan nilai perbandingan trigonometri di berbagai kuadran; pengertian konsep koordinat cartesius dan kutub; pengkonversian koordinat cartesius dan kutub; aturan sinus dan cosinus; penggunaan aturan sinus dan aturan cosinus; rumus luas segitiga; penentuan luas segitiga; identitas trigonometri; dan bentukbentuk persamaan trigonometri.

Berdasarkan hasil penelitian Gunawan (2016), disimpulkan bahwa permasalahan yang sering terjadi banyak peserta didik kurang mampu menguasai pelajaran matematika terutama yang berhubungan dengan soal cerita. Karena dalam menyelesaikan soal cerita tidak dapat dilakukan dengan satu langkah saja, tetapi harus melalui beberapa tahapan yang membutuhkan pemahaman dan keterampilan yang baik dalam memahami soal, melakukan perhitungan, dan menarik kesimpulan. Apabila peserta didik tidak menguasai salah satu tahap dalam menyelasikan soal cerita, maka siswa tersebut kesulitan bahkan gagal dalam menyelesaikan soal cerita matematika. 
Berdasarkan hasil penelitian Sujadi dan Widodo (2015) disimpulkan bahwa pada mata kuliah Trigonometri seringkali terjadi kesalahan konsep (memahami masalah dan membuat rencana untuk menyelesaikan masalah), kesalahan perhitungan (melaksanakan rencana yang telah dibuat untuk menyelesaikan masalah), kesalahan kebiasaan serta kesalahan dalam penegasan jawaban (memeriksa kembali jawaban). Berdasarkan hasil penelitian yang dilakukan Jingga, dkk. (2017), disimpulkan bahwa kesalahan yang dilakukan semua kelompok siswa dalam meyelesaikan masalah trigonometri adalah kesalahan berupa memutuskan menggunakan strategi menjabarkan masing-masing hubungan perbandingan trigonometri yang mengakibatkan perhitungan menjadi rumi. Penyebabnya adalah ketidakmampuan siswa menentukan hubungan antarrumus pada identitas trigonometri, kesalahan menuliskan tanda operasi matematika, kesalahan menuliskan tanda operasi matematika, dan kesalahan dalam melakukan operasi hitung bentuk aljabar. Penyebab lainnya adalah siswa tidak teliti saat melakukan perhitungan.

Berdasarkan hasil penelitian Imelda (2018), disimpulkan bahwa mahasiswa mengalami kesulitan penggunaan konsep persamaan dan pertidaksamaan kuadrat dan penggunaan konsep rumus-rumus trigonometri. Mahasiswa juga kesulitan dalam penggunan prinsip barisan bilangan dan menyelesaikan penyelesaian persamaan trigonometri dan mengungkapkan informasi dari soal pemecahan masalah dan kesalahan perhitungan. Faktor penyebabnya adalah adanya beberapa konsep dan prinsip aljabar dan trigonometri yang digunakan dalam menyelesaikan masalah masih belum dikuasi dengan baik oleh mahasiswa dan kurang teliti dalam melakukan perhitungan.

Hasil penelitian Julian, dkk. (2016), disimpulkan bahwa jenis-jenis kesalahan yang dilakukan siswa dalam menyelesaikan soal operasi pecahan bentuk aljabar yaitu kesalahan konseptual dan kesalahan prosedural. Kesalahan konseptual meliputi kesalahan konsep, prinsip, dan fakta. Sedangkan kesalahan prosedural meliputi kesalahan prosedur tidak lengkap, kesalahan mengerjakan sembarangan, kesalahan operasi hitung, dan kesalahan menyederhanakan pecahan bentuk aljabar. 
Kemampuan berhitung sangat penting dikuasasi oleh peserta didik meskipun pada anak usia dini, karena dalam kehidupan sehari-hari manusia tidak bisa lepas dari hitungan-hitungan. Menurut Marlina dan Purwadi (2014), berhitung adalah suatu proses menjumlahkan, mengurangi, mengalikan, dan membagi angka-angka yang sesuai dengan tata cara yang sudah ditentukan sebelumnya. Menurut Naga (Romlah, dkk., 2016) kemampuan berhitung adalah upaya mengenal matematika yang berkenaan dengan sifat dan hubungan bilanganbilangan nyata dan dengan perhitungan mereka terutama menyangkut penjumlahan, pengurangan, perkalian, dan pembagian. Sudaryanti (Romlah, dkk., 2016) mengungkapkan bahwa penjumlahan, pengurangan, perkalian, dan pembagian merupakan operasi bilangan yang sangat dasar. Seringkali faktorfaktor yang menyebabkan terjadinya kesalahan peserta didik adalah tingkatan operasi hitung, mengoperasikan, dan langkah langkah pengerjaannya (Ugi, dkk., 2016).

Aljabar juga merupakan salah satu cabang matematika yang penting. Sama pentingnya dengan beberapa cabang ilmu matematika lainnya seperti aritmatika, geometri, dan analisis. Menurut Agustina (2016), penyelesaian soal matematika sering kali menggunakan konsep aljabar. Konsep aljabar tidak hanya berhenti digunakan pada jenjang sekolah menengah, tetapi sampai pada jenjang perguruan tinggi, khussusnya untuk mahasiswa pendidikan matematika. Akan tetapi, dalam penerapan konsep aljabar, masih terdapat mahasiswa yang melakukan kesalahan ketika menyelesaikan soal matematika perkuliahan yang melibatkan aljabar. Kesalahan yang tampak adalah kesalahan konsep, memilih metode penyelesaian, dan prosedural. Salah satu materi aljabar yang dipelajari adalah faktorisasi aljabar. Pemfaktoran atau faktorisasi bentuk aljabar adalah menyatakan bentuk penjumlahan menjadi suatu bentuk perkalian dari bentuk aljabar tersebut. Misalnya, prosedur faktorisasi $x^{2}+x-6$ menjadi $(x-2)(x+3)$, yang dapat dilihat sebagai peubah sesuatu menjadi sesuatu yang berbeda (Tall dan Gray dalam Zubainur, dkk., 2017).

Berdasarkan pengalaman peneliti mengajar di kelas, mahasiswa tidak mengalami kesulitan pada konsep trigonometri. Kebanyakan dari mahasiswa 
apabila ditanya terkait konsep perbandingan trigonometri, mahasiswa bisa menjawab. Akan tetapi, apabila diberikan permasalahan tentang pemecahan masalah trigonometri yang menggunakan kemampuan berhitung dan menyederhanakan konsep aljabar, banyak mahasiswa yang mengalami kesulitan dan tidak dapat menjawab dengan benar. Oleh karenanya, peneliti melakukan penelitian tentang pengaruh antara kemampuan berhitung dan menyederhanakan bentuk aljabar terhadap kemampuan menyelesaikan masalah trigonometri.

\section{METODE}

Penelitian menggunakan metode deskriptif karena peneliti menuturkan dan menafsirkan data yang berhubungan dengan masalah penelitian berdasarkan situasi dan fakta-fakta, terutama yang berkaitan dengan hubungan antarvariabel. Variabel merupakan hal yang sangat penting dalam mendeteksi suatu masalah yang diungkapkan. Variabel penelitian yang diamati adalah kemampuan berhitung, menyederhanakan bentuk aljabar, dan menyelesaikan masalah trigonometri.

Bentuk penelitian yang digunakan dalam penelitian adalah studi hubungan (interrelationship studies). Banyak fakta-fakta yang ternyata harus dihubungkan satu dengan yang lain, agar suatu kodisi atau peristiwa dapat dipahami secara baik. Peneliti menggunakan bentuk studi hubungan yang searah untuk mengetahui pengaruh kemampuan berhitung dan menyederhanakan aljabar terhadap kemampuan menyelesaikan masalah trigonometri.

Penelitian dilaksanakan di Program Studi Pendidikan Matematika IKIP PGRI Pontianak. Populasi penelitian yaitu seluruh mahasiswa Pendidikan Matematika IKIP PGRI Pontianak yang mengambil mata kuliah Trigonometri tahun akademik 2017/2018. Populasi berjumlah 100 orang yang terbagi menjadi 3 kelas yaitu kelas AP, BP, dan CP. Sedangkan yang dijadikan sampel adalah mahasiswa kelas AP. Teknik pengambilan sampel menggunakan cluster random sampling. Teknik pengumpul data menggunakan soal tes. Alat pengumpul data yang digunakan adalah tes kemampuan menghitung, menyederhanakan bentuk aljabar, dan menyelesaikan masalah trigonometri. Soal tes adalah tes tertulis 
dalam bentuk esai sebanyak 5 butir soal untuk masing-masing tes. Teknik analisis data yang digunakan dalam penelitian yaitu uji parametrik berupa uji regresi.

\section{HASIL DAN PEMBAHASAN}

\section{Hasil}

Informasi kemampuan berhitung mahasiswa diperoleh dengan memberikan tes kemampuan berhitung pada mahasiswa Program Studi Pendidikan Matematika IKIP PGRI Pontianak. Bobot skor maksimum untuk tes kemampuan berhitung adalah 100 sedangkan bobot skor minimumnya adalah 0 .

Tabel 1 Deskripsi Kemampuan Berhitung

\begin{tabular}{|c|c|c|c|c|}
\hline $\begin{array}{c}\text { Banyak } \\
\text { Mahasiswa }\end{array}$ & Skor Maks & Skor Min & Rata-Rata & Standar Deviasi \\
\hline 33 & 90 & 15 & 36,89 & 21,45 \\
\hline
\end{tabular}

Hanya 7 dari 33 mahasiswa yang mengerjakan tes tersebut "tuntas" dengan kriteria ketuntasan kemampuan berhitung sebesar 60. Artinya hanya sekitar 21,21\% saja mahasiswa Pendidikan Matematika yang memiliki kemampuan berhitung, sedangkan yang lainnya masih perlu pembinaan dan perhatian khusus. Walaupun ada beberapa mahasiswa yang sudah mampu dalam menyelesaikan masalah operasi hitung, namun jumlahnya masih sedikit jika dibandingkan dengan jumlah mahasiswa yang belum mampu menyelesaikan masalah operasi hitung.

Kemampuan menyederhanakan bentuk aljabar mahasiswa diperoleh dengan memberikan tes kemampuan menyederhanakan bentuk aljabar pada mahasiswa Program Studi Pendidikan Matematika IKIP PGRI Pontianak. Bobot skor maksimum adalah 100 sedangkan bobot skor minimum adalah 0 .

Tabel 2 Deskripsi Kemampuan Menyederhanakan Bentuk Aljabar

\begin{tabular}{|c|c|c|c|c|}
\hline $\begin{array}{c}\text { Banyak } \\
\text { Mahasiswa }\end{array}$ & Skor Maks & Skor Min & Rata-Rata & Standar Deviasi \\
\hline 33 & 75 & 15 & 44,39 & 16,62 \\
\hline
\end{tabular}

Hanya 7 dari 33 mahasiswa yang mengerjakan tes tersebut "tuntas" dengan kriteria ketuntasan menyederhanakan bentuk aljabar sebesar 60. Dengan demikian, berarti hanya sekitar $21,21 \%$ saja mahasiswa Pendidikan Matematika 
yang memiliki kemampuan menyederhanakan bentuk aljabar, sedangkan yang lainnya masih perlu pembinaan dan perhatian khusus. Meskipun terdapat beberapa mahasiswa yang sudah mampu dalam menyederhanakan bentuk aljabar, namun jumlahnya masih sedikit jika dibandingkan dengan jumlah mahasiswa yang belum mampu menyederhanakan bentuk aljabar.

Informasi kemampuan menyelesaikan masalah trigonometri mahasiswa diperoleh dengan memberikan tes kemampuan menyelesaikan masalah trigonometri pada mahasiswa Program Studi Pendidikan Matematika IKIP PGRI Pontianak. Bobot skor maksimum adalah 100 sedangkan bobot skor minimumnya adalah 0 .

Tabel 3 Deskripsi Kemampuan Menyelesaikan Masalah Trigonometri

\begin{tabular}{|c|c|c|c|c|}
\hline $\begin{array}{c}\text { Banyak } \\
\text { Mahasiswa }\end{array}$ & $\begin{array}{c}\text { Skor } \\
\text { Maksimum }\end{array}$ & $\begin{array}{c}\text { Skor } \\
\text { Minimum }\end{array}$ & Rata-rata & Standar Deviasi \\
\hline 33 & 90 & 13 & 50,06 & 15,93 \\
\hline
\end{tabular}

Hanya 9 dari 33 mahasiswa yang mengerjakan tes tersebut "tuntas" dengan kriteria ketuntasan kemampuan menyelesaikan masalah trigonometri sebesar 60 . Artinya hanya sekitar 27,27 \% saja mahasiswa Pendidikan Matematika yang memiliki kemampuan menyelesaikan masalah trigonometri, sedangkan yang lainnya masih perlu pembinaan dan perhatian khusus. Walaupun ada beberapa mahasiswa yang sudah mampu dalam menyelesaikan masalah trigonometri, namun jumlahnya masih relatif sedikit jika dibandingkan dengan jumlah mahasiswa yang belum mampu menyelesaikan masalah trigonometri.

\section{Pengaruh Kemampuan Berhitung terhadap Kemampuan Menyelesaikan Masalah Trigonometri}

Berdasarkan hasil analisis data dari skor kemampuan berhitung dan menyelesaikan masalah trigonometri mahasiswa diperoleh angka konstan dari unstandardized coefficients $\mathrm{a}=36,816$. Hal tersebut berarti, jika kemampuan berhitung mahasiswa $=0$, maka nilai konstan kemampuan menyelesaikan masalah trigonometri mahasiswa sebesar 36,816. Selanjutnya diperoleh angka koefisien regresi $b=0,359$. Hal tersebut berarti bahwa setiap penambahan $1 \%$ kemampuan 
berhitung mahasiswa, maka akan meningkat pula kemampuan menyelesaikan masalah trigonometri mahasiswa sebesar 0,359. Karena angka koefisien yang diperoleh adalah positif (+), maka terdapat pengaruh yang positif antara kemampuan berhitung mahasiswa terhadap kemampuan menyelesaikan masalah trigonometri mahasiwa. Sehingga persamaan regresinya adalah $\mathrm{Y}=36,816+$ $0,359 X$.

Hasil analisis data diperoleh nilai signifikansi sebesar 0,004. Karena nilai signifikansi yang diperoleh lebih kecil dari nilai $\alpha=0,05$ (5\%), maka disimpulkan bahwa kemampuan berhitung mahasiswa berpengaruh positif terhadap kemampuan menyelesaikan trigonometri mahasiswa. Berdasarkan hasil analisis data diperoleh nilai $\mathrm{R}$ square sebesar 0,234 . Nilai tersebut berarti bahwa pengaruh kemampuan berhitung mahasiswa terhadap kemampuan menyelesaikan masalah trigonometri mahasiswa adalah sebesar 23,4\%, sedangkan 76,6\% kemampuan menyelesaikan masalah trigonometri dipengaruhi oleh variabel lain.

\section{Pengaruh Kemampuan Menyederhanakan Bentuk Aljabar terhadap Kemampuan Menyelesaikan Masalah Trigonometri}

Berdasarkan hasil analisis data diperoleh angka konstan dari unstandardized coefficients $\mathrm{a}=31,067$. Hal tersebut berarti, jika kemampuan menyederhanakan bentuk aljabar mahasiswa $=0$, maka nilai konstan kemampuan menyelesaikan masalah trigonometri mahasiswa sebesar 31,067. Selanjutnya diperoleh angka koefisien regresi $b=0,428$. Hal tersebut berarti bahwa setiap penambahan $1 \%$ kemampuan menyederhanakan bentuk aljabar mahasiswa, maka akan meningkat pula kemampuan menyelesaikan masalah trigonometri mahasiswa sebesar 0,428. Karena angka koefisien yang diperoleh adalah positif (+), maka terdapat pengaruh yang positif antara kemampuan menyederhanakan bentuk aljabar mahasiswa terhadap kemampuan menyelesaikan masalah trigonometri mahasiwa. Sehingga persamaan regresinya adalah $\mathrm{Y}=31,067+0,428 \mathrm{X}$.

Hasil analisis data diperoleh nilai signifikansi sebesar 0,009. Karena nilai signifikansi yang diperoleh lebih kecil dari nilai $\alpha=0,05$ (5\%), maka disimpulkan bahwa kemampuan menyederhanakan bentuk aljabar mahasiswa berpengaruh 
positif terhadap kemampuan menyelesaikan trigonometri mahasiswa. Berdasarkan hasil analisis data diperoleh pula nilai $\mathrm{R}$ square sebesar 0,199 . Nilai tersebut berarti bahwa pengaruh kemampuan menyederhanakan bentuk aljabar mahasiswa terhadap kemampuan menyelesaikan masalah trigonometri mahasiswa adalah sebesar 19,9\%, sedangkan 80,1\% kemampuan menyelesaikan masalah trigonometri dipengaruhi oleh variabel lain.

\section{Pengaruh Kemampuan Berhitung dan Menyederhanakan Bentuk Aljabar Secara Bersama-sama (Simultan) terhadap Kemampuan Menyelesaikan Masalah Trigonometri}

Berdasarkan hasil analisis data dari skor kemampuan berhitung dan menyederhanakan bentuk aljabar (secara besama-sama) terhadap skor kemampuan menyelesaikan masalah trigonometri mahasiswa diperoleh angka konstan dari unstandardized coefficients $\mathrm{a}=28,887$, angka koefisien regresi $\mathrm{b}_{1}=0,258$, serta angka koefisien $b_{2}=0,263$. Sehingga persamaan regresinya adalah $Y=28,887+$ $0,258 \mathrm{X}_{1}+0,263 \mathrm{X}_{2}$. Setelah menghitung $\mathrm{F}$ simultan, diperoleh nilai signifikansi sebesar 0,006. Karena nilai signifikansi yang diperoleh lebih kecil dari nilai $\alpha=$ 0,05 (5\%), maka disimpulkan bahwa kemampuan berhitung mahasiswa dan kemampuan menyederhanakan bentuk aljabar mahasiswa secara bersama-sama berpengaruh positif terhadap kemampuan menyelesaikan trigonometri mahasiswa.

Berdasarkan hasil analisis data diperoleh pula nilai $\mathrm{R}$ square sebesar 0,29. Nilai tersebut berarti bahwa pengaruh kemampuan berhitung mahasiswa dan menyederhanakan bentuk aljabar mahasiswa secara simultan terhadap kemampuan menyelesaikan masalah trigonometri mahasiswa adalah sebesar 29\%, sedangkan $71 \%$ kemampuan menyelesaikan masalah trigonometri dipengaruhi oleh variabel lain.

\section{Pembahasan}

Berdasarkan informasi dari Ketua Program Studi Pendidikan Matematika, penyebaran mahasiswa dilakukan secara merata. Artinya tidak ada kelas yang pandai atau kelas tidak pandai. Mahasiwa yang pandai dan tidak pandai saling 
berbaur, sehingga setiap kelas kemampuannya homogen. Menyikapi keadaan tesebut, peneliti menggunakan cluster random sampling untuk mengambil sampel yang akhirnya terpilihlah kelas AP yang terdiri dari 33 mahasiswa.

Jumlah soal tes untuk mengetahui kemampuan berhitung mahasiswa sebanyak 5 butir soal. Dari 33 orang mahasiswa yang mengerjakan soal tes, hanya 7 orang saja yang memperoleh skor melebihi nilai KKM, yakni 60. Hal tersebut berarti masih banyak mahasiswa Pendidikan Matematika IKIP PGRI Pontianak yang belum menguasai kemampuan berhitung dengan baik. Dari analisis jawaban mahasiswa, kebanyakan salah dalam menentukan mana dahulu yang dikerjakan antara penjumlahan dengan perkalian, penjumlahan dengan pembagian, pengurangan dengan pembagian, dan pengurangan dengan perkalian. Terdapat juga mahasiswa yang tidak hafal pembagian dan tidak dapat mengerjakan operasi pada pecahan. Hasil penelitian yang dilakukan mendukung hasil penelitian Yensy (2018) yang menyimpulkan bahwa 28,5\% mahasiswa salah dalam melakukan perhitungan dan menjadi penyebabnya adalah mahasiswa kurang teliti, terburuburu dalam mengerjakan serta ada yang tidak memahami konsep membilang.

Jumlah soal tes untuk mengetahui kemampuan menyederhanakan bentuk aljabar mahasiswa sebanyak 5 butir soal. Dari 33 orang mahasiswa yang mengerjakan soal tes, hanya 7 orang saja yang memperoleh skor melebihi nilai KKM, yakni 60. Hal tersebut berarti masih banyak mahasiswa Pendidikan Matematika IKIP PGRI Pontianak yang belum mampu menyederhanakan bentuk aljabar dengan baik. Dari analisis jawaban mahasiswa, kebanyakan salah dalam memfaktorkan dan menentukan tanda (-) atau (+) pada saat menyederhanakan bentuk aljabar. Terdapat juga mahasiswa yang tidak dapat menyelesaikan operasi penjumlahan bentuk aljabar yang sejenis. Hasil penelitian yang dilakukan mendukung hasil penelitian Widiyanti, dkk. (2015) yang kesimpulannya adalah kesalahan yang sering dilakukan peserta didik dominannya adalah kesalahan konsep.

Jumlah soal tes untuk mengetahui kemampuan menyelesaikan masalah trigonometri mahasiswa sebanyak 5 butir soal. Dari 33 orang mahasiswa yang mengerjakan soal tes, hanya 9 orang yang memperoleh skor melebihi KKM, yakni 
60. Hal tersebut berarti masih banyak mahasiswa Pendidikan Matematika IKIP PGRI Pontianak yang belum mampu menyelesaikan masalah trigonometri dengan baik. Dari analisis jawaban mahasiswa, kebanyakan tidak dapat meyelesaikan persamaan 1 variabel, operasi pada pecahan, dan tidak hafal nilai fungsi trigonometri untuk sudut-sudut istimewa. Hal tersebut mendukung hasil penelitian Abidin (2012) yang menyimpulkan bahwa kecenderungan mahasiswa mengalami kesalahan prinsip yaitu kurang memahami konsep-konsep yang ada dalam materi trigonometri.

Hasil penelitian Ardiawan (2015) menyimpulkan bahwa permasalahan yang peneliti amati di kelas adalah kebanyakan mahasiswa masih sering mengalami salah hitung, salah memfaktorkan, dan salah mengoperasikan operasi hitung aljabar. Akibatnya penskoran hasil pembelajaran tidak maksimal. Konsep trigonometrinya sudah benar, tetapi pengoperasian bentuk aljabarnya yang sering mengalami kesalahan. Begitu juga permasalahan yang peneliti amati di kelas yang diajarkan tanpa scientific. Kebanyakan mahasiswa masih sering mengalami kekeliruan dalam pengoperasian bentuk aljabar.

Berdasarkan hasil analisis data, diperoleh informasi bahwa terdapat pengaruh yang positif antara kemampuan berhitung mahasiswa dan kemampuan menyelesaikan masalah trigonometri. Walaupun pengaruh yang diberikan kemampuan berhitung hanya sebesar 23,4\%, akan tetapi sangat penting mahasiswa memiliki kemampuan berhitung. Karena dalam menyelesaikan masalah trigonometri diperlukan kemampuan berhitung yang baik. Seperti contoh, walaupun konsep perbandingan trigonometri mahasiswa sudah benar, akan tetapi dalam menghitungnya salah, maka menjadi salah penyelesaiannya. Selanjutnya juga diperoleh informasi bahwa terdapat pengaruh yang positif antara kemampuan menyederhanakan bentuk aljabar mahasiswa dan kemampuan menyelesaikan masalah trigonometri. Walaupun pengaruh yang diberikan kemampuan menyederhanakan bentuk aljabar hanya sebesar 19,9\%, akan tetapi sangat penting mahasiswa memiliki kemampuan menyederhanakan bentuk aljabar karena dalam menyelesaikan masalah trigonometri diperlukan kemampuan menyederhankan bentuk aljabar yang baik. Seperti contoh, walaupun konsep perbandingan 
trigonometri mahasiswa sudah benar, akan tetapi dalam menyederhanakannya salah, maka menjadi salah pula penyelesaiannya.

Berdasarkan hasil analisis diperoleh pula kesimpulan bahwa secara bersama-sama terdapat pengaruh yang positif antara kemampuan berhitung dan kemampuan menyederhanakan bentuk aljabar terhadap kemampuan menyelesaikan masalah trigonometri. Tidak dapat dipungkiri, dalam meyelesaikan masalah trigonometri sangat diperlukan kemampuan berhitung serta kemampuan menyederhanakan bentuk aljabar yang baik. Semakin baik kemampuan berhitung dan kemampuan menyederhanakan bentuk aljabar seorang mahasiswa, maka akan semakin baik pula penyelesaian masalah trigonometri mahasiswa tersebut.

Hasil penelitian yang dilakukan mendukung penelitian Nurlaela, dkk. (2018) yang menyimpulkan bahwa: (1) Ada pengaruh antara kemampuan verbal terhadap kemampuan menyelesaikan soal cerita matematika; (2) Ada pengaruh antara kemampuan berhitung terhadap kemampuan menyelesaikan soal cerita matematika; dan (3) Ada pengaruh antara kemampuan verbal dan berhitung terhadap kemampuan menyelesaikan soal cerita matematika. Artinya bahwa semakin baik kemampuan verbal dan kemampuan berhitung, maka semakin baik pula kemampuan menyelesaikan soal cerita matematikanya.

\section{SIMPULAN}

Berdasarkan hasil analisis data, maka dapat disimpulkan: (1) Terdapat pengaruh yang positif antara kemampuan berhitung terhadap kemampuan menyelesaikan masalah trigonometri pada mahasiswa Pendidikan Matematika IKIP PGRI Pontianak sebesar 23,4\%; (2) Terdapat pengaruh yang positif antara kemampuan menyederhanakan bentuk aljabar terhadap kemampuan menyelesaikan masalah trigonometri pada mahasiswa Pendidikan Matematika IKIP PGRI Pontianak sebesar 19,9\%; dan (3) Terdapat pengaruh yang positif secara bersama-sama antara kemampuan berhitung dan kemampuan menyederhanakan bentuk aljabar terhadap kemampuan menyelesaikan masalah trigonometri pada mahasiswa Pendidikan Matematika IKIP PGRI Pontianak sebesar $29 \%$. 


\section{DAFTAR PUSTAKA}

Abidin, Z. 2012. Analisis Kesalahan Mahasiswa Prodi Pendidikan Matematika Fakultas Tarbiyah IAIN Ar-Raniry dalam Mata Kuliah Trigonometri dan Kalkulus 1. Jurnal Ilmiah Didaktika, 8(1): 183-196.

Agustina, E. N. S. 2016. Konsep Aljabar yang Terlupakan. Jurnal Edukasi, 2(1): 25-34.

Ardiawan, Y. 2015. Efektivitas Pendekatan Scientific dalam Mata Kuliah Trigonometri pada Mahasiswa Pendidikan Matematika IKIP PGRI Pontianak. Jurnal Pendidikan Matematika Aksioma, 4(2): 30-41.

Gunawan, A. 2016. Analisis Kesalahan dalam Menyelesaikan Soal Cerita pada Mata Pelajaran Matematika Siswa Kelas V SDN 59 Kota Bengkulu. Jurnal PGSD: Jurnal Ilmiah Pendidikan Guru Sekolah Dasar, 9(2): 216-225.

Imelda. 2018. Analisis Kesulitan Mahasiswa dalam Menyelesaikan Soal Pemecahan Masalah pada Mata Kuliah Aljabar dan Trigonometri. MES (Journal of Mathematics Education and Science), 4(1): 49-46.

Julian, R. S., Bennu, S., \& Lefrida, R. 2016. Analisis Kesalahan Siswa Kelas VIII SMP Negeri 19 Palu dalam Menyelesaikan Soal Operasi Pecahan Bentuk Aljabar. Jurnal Elektronik Pendidikan Matematika Tadulako, 4(2): 248-262.

Jingga, A. A., Mardiyana, \& Setiawan, R. 2017. Analisis Kesalahan Siswa dalam Menyelesaikan Soal Identitas Trigonometri pada Siswa Kelas X Semester 2 SMA Negeri 1 Kartasura Tahun Ajaran 2015/2016. Jurnal Pendidikan Matematika dan Matematika (JPMM) Solusi, 1(5): 48-62.

Marlina, R. \& Purwadi. 2014. Upaya Meningkatkan Kemampuan Berhitung melalui Model Pembelajaran Kooperatif Struktural Permainan Ular Tangga TK Marta'ush Shibyan Singocandi Kudus. Jurnal Penelitian PAUDIA, 3(2): 63-83.

Nurlaela, L., Budiyono, \& Purwoko, Y. R. 2018. Pengaruh Kemampuan Verbal dan Kemampuan Berhitung terhadap Kemampuan Menyelesaikan Soal Cerita Matematika Siswa Kelas VII SMP/MTs Se Kecamatan Alian. Jurnal Ekuivalen Pendidikan Matematika, 35(1): 52-63.

Romlah, M., Kurnih, N., \& Wembrayarli. 2016. Peningkatan Kemampuan Berhitung Anak melalui Kegiatan Bermain Sempoa. Jurnal Jurnal Ilmiah Potensia, 1(2): 72-77.

Ugi, L. A., Djadir, \& Darwis, M. 2016. Analisis Kesalahan Siswa pada Operasi Hitung Campuran Bilangan Bulat dan Alternatif Pemecahannya. Jurnal Daya Matematis, 4(1): 34-50.

Yensy, N. A. 2018. Diagnosis Kesalahan Mahasiswa dalam Menyelesaikan Soal Perhitungan Peluang pada Mata Kuliah Statistika Matematika. Jurnal Pendidikan Eksakta, 2(4): 145-150. 
Widiyanti, P., Zubaidah, \& Yani, A. 2015. Analisis Kesulitan Siswa dalam Menyelesaikan Soal Materi Pecahan Bentuk Aljabar di Kelas VIII SMP. Jurnal Pendidikan dan Pembelajaran Khatulistiwa, 4(9): 1-17.

Widodo, S. A. \& Sujadi, A. A. 2015. Analisis Kesalahan Mahasiswa dalam Memecahkan Masalah Trigonometri. Jurnal Sosiohumaniora, 1(1): 51-63.

Zubainur, C. M., Dazrullisa, \& Marwan. 2017. Kesalahan Siswa pada Materi Aljabar melalui Pembelajaran oleh Calon Guru yang Mendapat Pendampingan. Jurnal Didaktik Matematika, 4(1): 68-79. 